\title{
Perjumpaan school: a new model of character learning in plural community
}

\author{
Abdul Quddus \\ Universitas Islam Negeri Mataram, Indonesia. \\ abdul.quddus@uinmataram.ac.id \\ DOI: $10.18326 /$ attarbiyah.v5i2.153-168
}

$\begin{array}{ccc}\text { Submitted: } & \text { Accepted: } & \text { Published: } \\ \text { 20 October 2020 } & \text { 11 January 2021 } & \text { 13 January 2021 }\end{array}$

\begin{abstract}
Family, education school and community are strategic educational institutions in shaping the character of the nation that upholds integrity, honesty and commitment, but the fact is that these various institutions have not yet fully embodied the characters they aspire. Many character problems and abnormal social relations are experienced by learners in Indonesian educational institutions. Various models of character internalization emerged and developed to respond to this fact, including the Integrated Islamic School (SIT) education model, Living Values Education (LVE), The ESQ Way 165 and the Perjumpaan School Community. This article aims to analyze the character learning model developed by Perjumpaan School. This study uses qualitative research with descriptive analysis as a model for data analysis. This study found that Perjumpaan School has developed a new model in character learning. Perjumpaan School emphasized mental state management and languaging. Mental state is related to positive feelings or emotions while languaging is the use of norms inherent in language action. Positivity mental state and languaging in every encounter are efforts to normalize social relations that are open, tolerant and mutually acceptable to plural society.
\end{abstract}

Keywords: Perjumpaan school, learning, character, mental state, languaging. 


\section{INTRODUCTION}

It is an open secret that social relations in educational institutions have not fully improved and are still colored by suspicion, class sentiments, primordial sentiments and unequal relations between the individuals in them. Social relations lead to individualism and leave the spirit of collectivity and togetherness which should characterize social institutions, especially educational institutions or institutions. This fact, confirms the strengthening of educational patterns and paradoxical regeneration, internally strengthens group solidity, but simultaneously in external relations strengthens primordial sentiment. In the end, this type of education creates friction, tension and social conflict, especially in plural societies in terms of ethnicity, religion, race and culture.

The rise of anarchist behavior, brawls, pornography, pornographic acts of drug abuse among students, promiscuity, corruption, crime, environmental damage, terrorism, radicalism and various other pathological acts are indications of acute problems in the development of this nation's character. This phenomenon of the fading of national values has become news in print and electronic media and we even experience it ourselves in our daily social life.

Lickona (1992) analyzed that there are 10 signs that a nation is heading to the brink of destruction, namely; (1) increasing violence among adolescents; (2) a culture of dishonesty; (3) fanatical attitude towards the group/peer group; (4) lack of respect for parents \& teachers; (5) the increasingly blurred good \& bad morals; (6) deteriorating language use; increased self-destructive behavior, such as drug use, alcohol \& casual sex; (8) low sense of responsibility as individuals \& as citizens; (9) decreased work ethic \& mutual suspicion; (10) lack of concern among people.

The description above has raised awareness of the urgency of the agenda for breakthroughs in order to shape and foster the character of students as the nation's next generation. Besides the pressing challenges of the social problems above, it has been a perennial belief from the past that the core of education is character building. A number of educational experts try to formulate concepts about character education, and some of them have even gone a long way in putting it into practice. For example, The ESQ Model, a systematic mechanism regulating the three dimensions of humans, namely body, mind and soul or physical, mental and spiritual dimensions in one integral part in the harmony and unity of tawhid. In addition, Living Values Education (LVE) is an educational program 
that offers training and practical methodologies for educators, facilitators, social workers, parents and child assistants to help them explore and develop universal values, so they can associate these values in skills. social-emotional and intrapersonal-interpersonal.

Referring to the Islamic education tradition, character terminology has been ingrained for thousands of years in the monumental works of figures such as the Book of Ihya Ulumuddin, Ayyuhal walad writren by Imam al-Ghazali (1111 AD), Ibnu Miskawaih (1030 AD) with Tahdzbul Akhlak and Az-Zarnuji (1243 AD). ) with the book Ta'limul Muta'allim (Quddus, 2014).

In practice, pesantren educational institutions have a strategic position in the world of education in Indonesia. As a form of education, pesantren has its own place in front of the community. This is because Islamic boarding schools have contributed greatly to the life of the nation and the development of community culture. Pesantren have been allegedly implementing character education for a long time. Pesantren as one of the subsystems of National Education which is indigenous to Indonesia, is even seen by many as having special advantages and characteristics in applying character education for their students (santri). This view seems to depart from the fact that: pesantren education is easier to shape the character of its students because this educational institution uses a boarding system that allows it to apply the values and world views it embraces in the daily life of its students.

The national commitment on the need for character education is imperatively stated in Law Number 20 of 2003 concerning the National Education System. In Article 3 it is stated that: "National education has the function of developing capabilities and shaping the character and civilization of a nation with dignity in the framework of the intellectual life of the nation, aiming at developing the potential of students to become human beings who believe and fear the Almighty God, have noble character, are healthy, knowledgeable, competent, creative, independent, and become democratic and responsible citizens".

Character education is the cultivation of habits about the good things in life, so that a person has high awareness and understanding, as well as concern and commitment to implementing wisdom in everyday life (Mulyasa, 2011). Further, Lickona (1992) defines character education as a deliberate effort to make someone understand, care and will act on the basis of ethical values. Character education is a plus character education, which 
involves aspects of knowledge (cognitive), feelings, and action. Lickona also stated that character is related to moral knowing, moral feeling and moral behavior.

From the academic side, character education is interpreted as value education, character education, moral education, character education, which aims to develop the ability of students to make good and bad decisions, maintain what is good, and realize that good in everyday life. wholeheartedly. Therefore, the psychological content of character education includes dimensions of moral reasoning, moral feeling, and moral behavior. In Koesoema's view, the explosive character education process pays attention to the human anthropological structure consisting of the body, spirit, and reason. (Koesoema, 2007)

The Indonesia Heritage Foundation states that there are nine important character values to be instilled in children, including: a) Love God and all His creation (love Allah, trust, reverence, loyalty). b) Responsibility, discipline and independence (responsibility, excellence, self-reliance, discipline, orderliness), c) Honesty/trustworthiness, wisdom (trustworthiness, reliability, honesty), d) Respect and courtesy (respect, courtesy, obedience), f . Affection, concern, and cooperation (love, compassion, caring, empathy, generousity, moderation, cooperation), g. Confidence, creative, hard work, and never give up (confidence, assertiveness, creativity, resourcarefulness, courage, determination and enthusiasm), h. Justice and leadership (justice, fairness, mercy, leadership), i. Kindness and humility (kindness, friendliness, humility, modesty), j. Tolerance, love peace, and unity (tolerance, flexibility, peacefulness, unity) (Megawangi, 2007).

Character education is starting to getattention from the government to immediately implement it in schools as the main program. The Ministry of National Education has launched a vision for the implementation of Character education in 20102014. The Directorate General of Primary and Secondary Education at the Ministry of National Education revealed that based on a study of religious values, social norms, law, academic ethics and human rights principles, values were identified which were grouped into five main values, including: (1) Religious, (2) Honest, (3) Tolerance, (4) Discipline, (5) Hard work, Creative, (7) Independent, (8) Democratic, (9) Curiosity, (10) National Spirit, (11) Love the Fatherland, (12) Respect Achievements, (13) Friendly/Communicative, (14) Love Peace, (15) Like to Read, (16) Care for the Environment, Care for Social, \& (18) Responsibility (Badan Penelitian dan Pengembangan Pusat Kurikulum, 2010). 
Perjumpaan School is an effort to normalize social relations whose theoretical model is generic so that it can be applied to various settings and also different contexts through regular meetings as a learning institution. The main components of Perjumpaan School are mental state (mental condition) and languaging which are shared models that everyone has universally. Learning to manage mental state and languaging in meeting spaces in a structured and measured manner will be a means of learning together living with the heart, with conscience and with universal moral values (Muadz, 2017).

Perjumpaan School was initiated as a place to practice universal values of language that would be able to normalize the abnormal social system, because the relations between subjects in the existing social system were still dominated by negative characters such as prejudice, presuppositions and pejorative assumptions against parties or another group.

Based on the background description above, Perjumpaan School can be offered as a character learning model in a plural society. This study wants to find out further about the Perjumpaan School's character learning theory and its practice.

\section{METHOD}

This research is a qualitative research by exploring primary data and secondary data (Moleong, 2006). The research stage is by examining in depth primary data about various models of character development, especially about Perjumpaan School, for example from the Perjumpaan School book trilogy, namely: 1) Anatomy of Social Systems, 2) Learning quadrants and 3) Perjumpaan School. For secondary data, the researcher examines books, writings, articles and journals that are relevant to the research theme. Data collection was carried out by documenting various books, articles and research on character education, for example the Perjumpaan School Practice book at the Himatussyarif Narmada Islamic Boarding School, West Lombok. Furthermore, the analysis is done deductively and inductively. The deductive method is used to obtain an overview of character learning, while the inductive method is used to reveal Perjumpaan School learning. The data that has been analyzed is then presented with a deductive method that departs from general theory to reach a conclusion which is the answer to the formulation of this research problem. 


\section{RESULTS AND DISCUSSION}

\section{Perjumpaan School: History and Existence}

This Perjumpaan School has been experimented with since 2013 in more than fifty places spread across the island of Lombok. These communities serve as community learning laboratories to create a social system that is open, tolerant, and mutually acceptable. These locations are scattered at several points in Labuapi, Lembar, Praya, Mantang, Mataram, Gunung Sari, and Narmada Districts. The initiator of Perjumpaan School is M. Husni Muadz Ph.D, a Linguist who graduated from Ohio and Arizona who works as a Lecturer at the University of Mataram. One of his works that is widely referred to in the West regarding the study of the three-dimensional structure of language is Coordinate Structures; A Planar Representation (Putrawan, 2018).

In practice, Perjumpaan School is a moral or character education model with a populist movement that has been experimenting for 3 years in communities and educational institutions by managing mental state practices and languaging practices. This has implications for building a spirit of learning, self-confidence, caring and social cooperation, tolerance, and a vision of life to be good people. It even has a direct impact on the skyrocketing academic achievement of students in schools. Positive mental state and languaging practices that are shared by everyone, which have been managed well, have been proven to provide the foundation for a life of character and have a direct impact on academic achievement (Taufik, 2017).

This context is what in Degeng (in Uno, 2012) is called Learning, namely an effort to teach students. In this sense, implicitly in learning there are activities to choose, determine and develop methods to achieve the desired learning outcomes. Learning is related to how (How to) teach students or how to make students learn easily and are motivated by their own willingness to learn what (what to) is actualized in the curriculum as the needs of students. Therefore, learning seeks to describe the values contained in the curriculum (Muhaimin, 2012).

Perjumpaan School has the following characteristics or characteristics: 1) The things that are practiced are almost unlimited, both those related to vertical activities towards God and horizontal activities towards fellow human beings. Perjumpaan School is a place or means of training to change the practice of encounters that are happening, by 
training together related to; a) how to manage the heart, by applying positivity in the encounter, b) how to speak according to normativity in every encounter, c) Taking action according to the commitment that was born according to the purpose of the encounter; 2) Internal Member Meeting; In order for the learning practice to continue, Perjumpaan School must have regular and periodic meetings; 3) The strategy of escorting learning activities, especially in the practice of implementing commitments; 4) Perjumpaan School does not require material financing. Activities in the learning workshop do not require funding, because the purpose of the encounter is to connect hearts, are non-material in nature. (Muadz, 2017)

Some of the principles that become the guideline in implementing Perjumpaan School are: a) Equality; in Perjumpaan School the subject value is used as a reference and not an attribute value, b) collectivity; in Perjumpaan School, togetherness or collectivity is essential to create collective conscience which is followed by collective action, c) Circularity, in Perjumpaan School there is a circular relationship between language and post-language action, d) Sustainability; in Perjumpaan School, the principle of learning is long life (long life learning) (Firdaus, et al, 2017).

Actions are verbal and physical expressions that are based on certain intentions and wills consciously when interacting with the outside world. Expressions without intention and will are not called actions. Human actions based on the type of relationship are as follows: 1) Trans-subjective actions, namely actions that are born when dealing with God (worship). This type of action perspective is a second person perspective (as a participant), that is, the learner subject consciously positions himself as a party interacting with the great subject. The competence resulting from the application of the principle of transubjective action is "trans-cognitive competence"; 2) Inter-subjective actions, namely actions that are born when the subject relates to others. The perspectives used in this type of action are the first and second person perspectives (first and second person perspectives) or as participants, namely the subject consciously positions himself as an active participant who is not distant in interactions with other people so that recognition of the existence of others is built. equal position. Competence resulting from the application of the principle of subjective internal action is "Recognitive competence"; 3) Subjective actions, namely actions that are born from interactions with objects. The perspective used is the third person perspective/ observer 
perspective, in which the subject consciously positions himself as an observer who is at a distance from the object. The competence that results from the application of the principles of objective action gives birth to "cognitive competence". (Muadz, 2017).

The three types of action and competence that they produce are integrated holonically as an illustration of the following figure

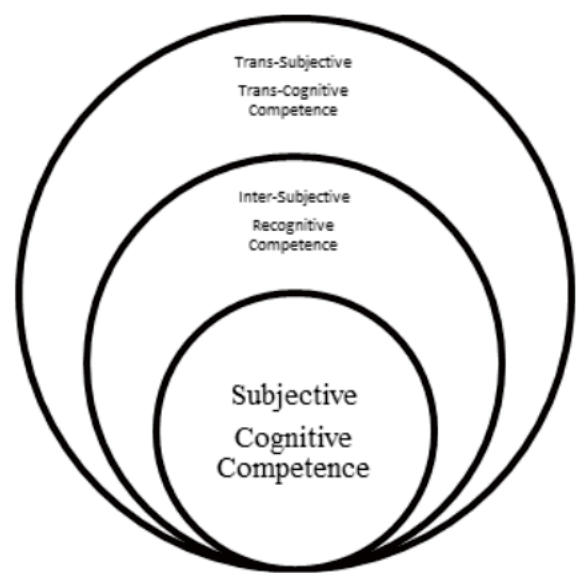

Encounter presupposes the recognition of equal dignity among subjects as a basis for mutual respect. The mentality that must operate in the encounter is positivity (affection, sincerity, optimism) because the purpose of the encounter is intersubjectivity. The exterior dimension of the encounter (verbal and non-verbal actions) is an expression of an inner attitude in the form of a mental state.

Learning is essentially a reciprocal transactional communication process, both between teachers and students, students and students to achieve predetermined goals. Transactional communication is a form of communication that can be accepted, understood and agreed upon by the parties involved in the learning process so that it shows the acquisition, mastery, outcome, process or learning function for the learning participants. Joyce stated four families of learning models, namely; a) Clumps of social interaction models, which are more oriented towards the ability to solve various social problems in the community. b) Information processing models, namely learning clusters that are more oriented towards mastering scientific disciplines. c) Personal development model, this model family is more oriented to the development of the personality of the learners. SelanJutnya model, d) Behaviorism Joyce, which is a model that is oriented towards behavior change. (Joyce, Weil, \& Calhoun, 2000) 


\section{Intentional State and Positive Languaging: Towards Heart Education}

There are two things that cannot be avoided in the community, namely emotioning and languaging. Emotioning or certain feelings when experiencing or doing something, such as feelings of like, boredom, sadness, and others. Emotioning and languaging operate in encounter and can express two groups of values; positivity or negativity.

Intentional state is the mental condition that underlies the expression of action. It consists of four broad categories which must always be in line with the type of action of language, namely: first: thinking (knowledge and thought) which is the basis of assertive action. The second emotioning (feeling) which is the basis of expressive action. The three desiring (desire) which is the basis for directive action. The fourth is willing (intention/will) which is the basis of commisive action.

The types of linguistic actions and language norms are as follows: 1) Assertive; namely the use of language to express or describe something and at the same time invite others to believe it. 2) Commissive; namely the use of language to make promises or commitments to do something to another party. 3) Directive; namely using language to ask the other party to do or not do something. 4)Expressive; namely using language to express feelings to other parties (Muadz, 2017).

Positive languaging is the habituation to practice universal moral norms in language, according to the types of speech act: assertive, namely using language to state or describe something at the same time inviting others to believe, commissive, namely using language for making promises or commitments to do something to others. Directive is using language to ask other parties to do or not do something. Expressive, namely using language to express feelings to others.

The type of speech act (language action) and the type of mental state according to its deontic value can be summarized in the matrix as follows:

Table 1. Language Action and Types of Mental State

\begin{tabular}{llll}
\hline No & \multicolumn{1}{c}{ Languaging } & \multicolumn{1}{c}{ Mental State } & \multicolumn{1}{c}{ Example } \\
\hline 1. & $\begin{array}{l}\text { Expressive, that is } \\
\text { language as a way to } \\
\text { express feelings. }\end{array}$ & $\begin{array}{l}\text { Emotioning, that is a feeling } \\
\text { that is the basis for expressive } \\
\text { expression. }\end{array}$ & $\begin{array}{l}\text { 1. Apologizing must depart } \\
\text { from guilt as its }\end{array}$ \\
\end{tabular}


2. Saying thank you must depart from gratitude / pleasure as an intentional state

3. Saying congratulations must depart from feeling happy for the success of others as its intentional state

2. Assertive, that is the Thinking, that is knowledge,
use of language to thought and rationality
describe or make
statements about
known truths and at
the same time invite
others to believe
them.

1. Statement of facts must depart from certain knowledge and is believed to be true as its intentional state

2. The description of the relationship of events must be based on certain thoughts or rationalities which become the intentional state

\begin{tabular}{|c|c|c|c|}
\hline 3. & $\begin{array}{l}\text { Directive, that is to } \\
\text { use language to ask } \\
\text { other people to do } \\
\text { something }\end{array}$ & $\begin{array}{l}\text { Desiring, that is the desire for } \\
\text { other people to do what is } \\
\text { asked }\end{array}$ & $\begin{array}{l}\text { 1. Ordering other people to } \\
\text { do one good must depart } \\
\text { from the desire for others } \\
\text { to do it as their } \\
\text { intentional state } \\
\text { 2. Praying to God must be } \\
\text { based on a strong hope } \\
\text { that God will grant his } \\
\text { request as his intentional } \\
\text { state }\end{array}$ \\
\hline 4. & $\begin{array}{l}\text { Commissive, that is } \\
\text { the language to } \\
\text { make a promise or } \\
\text { commitment to } \\
\text { make something } \\
\text { happen }\end{array}$ & $\begin{array}{l}\text { Willing, that is the will / } \\
\text { intention to carry out as } \\
\text { promised. Implementation of } \\
\text { transformative humanistic } \\
\text { learning }\end{array}$ & $\begin{array}{l}\text { 1. Promises to others to do } \\
\text { something must be based } \\
\text { on the intention or will } \\
\text { to realize that promise as } \\
\text { an intentional state }\end{array}$ \\
\hline
\end{tabular}

From the matrix above, it is clear that the act of language in an assertive form is closely related to values or principles which, if applied, will give birth to character or moral attitudes or actions. This model will in turn give birth to good social relations and systems 
or norms; conform to universal values. The principle values are: the values of truth, the values of honesty, the values of responsibility, the values of proof, the values of openness, the values of being kind, and the values of objective.

Apart from the values of Assertive action, also appeared the values of Commissive actions, for example regarding the value of certainty, sincerity, consistency and clarification. Then from the Directive action emerged the principles of tolerance, compassion, sportsmanship, loyalty to the truth. The last of the Expressive actions will give birth to the value of sincerity and respect.

The practice of this truth value will give birth to individuals with integrity and uphold the truth. If learning to apply the values or principles mentioned above is not carried out consciously and together through Perjumpaan School, and in all types of encounters, the opposite values will develop, namely negative values that will give birth to unequal social relations and systems. social abnormalities.

\section{Practice of Character Learning at Perjumpaan School}

Because everyone cannot avoid encounters, whether regular meetings or accidental meetings, these meetings become strategic places to practice the principles of balanced, open, and mutually acceptable relationships through emotional and languaging practices. Learning in schools is designed flexibly both in determining the type of activity that will become Perjumpaan School, the time or duration required so that it does not interfere with the system that has been formed and running. Perjumpaan School is not creating a new system, but rather filling the system (such as educational institutions) to make it more operational, productive and meaningful.

A good social system is determined by the quality of the encounter. The more quality the encounter, the better and better quality social relations or systems are created. Conversely, unqualified encounters will cause social relations to become increasingly tenuous. If encounter is a condition for the formation of social relations, and if the quality of the relations determines the quality of the social system formed, then there is no other choice but to increase the frequency of encounters between subjects and at the same time improve the quality of encounters. 
The necessary learning institutions cannot be found in the existing encounter institutions because the objective mindset of encounter is still instrumental. Therefore we need a learning institution specifically designed to improve the practice of encounter. The institution is a kind of meeting workshop, where each workshop has a community of learners who are committed to practicing together practicing improvements in the encounter. We call this encounter learning institution with a purpose like "Perjumpaan School" (if it is a meeting); This school does not have physical characteristics like an ordinary school, but the characteristic is that the community in it has a collective consciousness to continuously practice together in every encounter they practice values that will give birth to acceptance (Muadz, 2017).

The character configuration developed in Perjumpaan School is the totality of psychological and socio-cultural processes which can be grouped into: (1) spiritual \& emotional development; (2) intellectual development; (3) sports and kinesthetic (physical $\&$ kinesthetic development); and (4) affective and creativity development. The process is holistic and coherent, interrelated and complementary, and each conceptually constitutes a cluster of noble values which contains a number of values.

As for the level of the learning process, such conditions are caused by the ongoing education which emphasizes on the cognitive aspects alone, by ignoring the affective, psychomotor, and spiritual aspects. Whereas ideally, education is not just a transfer of knowledge (knowledge) from one person to another (several) people, but also transforms values into the soul, personality, and structure of human consciousness. The printout of the human personality is the result of a process of transforming knowledge and education which is carried out humanistically. A belief that requires an educational process with the aim of developing various aspects of humanity holistically, including physical-biological and spiritual psychology (Taufik, 2017).

The character education internalization strategy that applies in Perjumpaan School can be formulated as follows: (1) exemplary (uswatun hasanah), used to develop student personalities; (2) habituation, used to form character building, namely fostering disciplined and moral awareness; (3) learning by instruction, is used in all aspects of life in educational institutions and communities so that students can experience the values of education and at the same time the most effective means of internalizing character values; 
(4) learning by doing, used to instill noble values; (5) criticism, is used to learn to criticize properly and to accept criticism with sincerity; (6) leadership and independence, developed in various aspects of student life.

The Perjumpaan School system has implemented an integral education concept, an education system that not only focuses on learning which requires students to understand and master cognitive teaching materials in educational institutions and communities, but also how students can apply the knowledge they have acquired. through the learning process in everyday life in each meeting room. In this context, it is precisely what Gagne said that learning consists of three components, namely external conditions, namely the stimulus from the environment, internal conditions that describe the internal and cognitive states of students and learning outcomes that describe verbal information, intellectual skills, motor skills, attitudes, and tactics. cognitive. (Suryabrata, 2006).

There are two stages of implementing Character learning in Perjumpaan School, First: Starting Stages which consist of a) brainstorming, b) introduction to theoretical concepts, c) determining the type of activity, d) a joint declaration containing a joint commitment to start Perjumpaan School learning and a joint commitment to start normalizing mental state. The second stage: The meeting stage, namely: a) the encounter in the micro school, b) the encounter in the school macro (Firdaus et al, 2017).

The character values developed by Perjumpaan School include the first form of assertive, namely the value of truth, honesty, responsibility, proof, openness, kind thought and objectivity. Both commissive actions create values of certainty, sincerity, consistency and clarification. The three directives present the values of the principles of tolerance, compassion, sportsmanship, loyalty to the truth. The four expressive actions present the value of sincerity and mutual respect.

Wiliam Kilpatrick mentioned that one of the causes of a person's inability to act or have good character is that he does not practice moral doing even though he already has moral knowing. Thus, it can be understood that the success of character learning is very much dependent on whether or not there are: knowing, loving, and doing or acting (Juharyanto, 2017). In this case, Megawangi (in Majid \& Andayani, 2011) added that the three stages above need to be presented to students in a logical, rational and democratic way. This is the strength and advantage of Perjumpaan School in internalizing the values 
or characters above, Perjumpaan School has implemented the three steps and stages of internalizing the characters above.

The learning practice of Perjumpaan School in each community has its own specific focus and characteristics, such as: Perjumpaan School Community in Bangket Bilong village, especially for studentsin the form of learning English and IELTS (International English Language Testing System) at night, discussions at the drafter's house (M. Husni Muadz) every Saturday night, reading books 1 hour a day, presenting the reading results on Thursday and Saturday after Asar prayers, and learning English on Monday afternoons. As for the general public (children, parents, and mentors) in the form of harvesting molah maulana on Friday nights collectively (once a month), hizib (practices) every Thursday night, Al-Quran collectively, guarding ablution water, and social activities; the Midang village meeting school community in the form of saying greetings, keeping promises, paying attention to people talking, and reading books: and the Mantang village Perjumpaan School community in the form of sending greetings, helping parents (in kindness), reading 1 hour a day, presenting reading results for one week every night, and learning not to lie.

Perjumpaan School in its learning activities practices is more visible in strengthening the management of emotions (feelings), the ethics of language and actions. Every activity of encountering phenomena that occurs is an awareness of the equal dignity of fellow subjects which is the basis for the emergence of an attitude of mutual respect for one another. Perjumpaan school model is an educational model that teaches the participants (the community) to become human beings who have the nature and attitude of open, mutually acceptable and tolerant social relations, by managing emotioning and languaging practices (Wahab, 2019).

\section{CONCLUSION}

All social institutions, starting from family, school, and community, consist of encounter activities between components (subjects) in them. There is no social world without subject encounter. A good social system is basically determined by the quality of the encounter, the better the quality of the encounter, the better the social system. Perjumpaan School offers lifelong learning that uses each encounter as a school where the learning and practice 
of oral values of language action happen. Each encounter will eventually become a school where learning to practice positive languaging is in line with the mental state that is the basis.

The character values developed by Perjumpaan School include: first is in the form of assertive, namely the value of truth, honesty, responsibility, proof, openness, kind thought and objectivity. Second is commissive actions that is creating values of certainty, sincerity, consistency and clarification. Third is directives which presents the values of tolerance, compassion, sportsmanship, loyalty to the truth. Fourth is expressive actions that is presenting the value of sincerity and mutual respect.

\section{REFERENCES}

Badan Penelitian dan Pengembangan Pusat Kurikulum. (2010). Pengembangan Pendidikan Budaya $\mathcal{E}$ Karakter Bangsa. Jakarta: Kementerian Pendidikan Nasional.

Firdaus, M. etal. (2017), Praktek Sekolah Perjumpaan di Pondok Pesantren. Mataram: Sanabil. Joyce, B. R., Weil, M., \& Calhoun, E. (2000). Models of Teaching. Boston: Allyn And Bacon. Juharyanto. (2017). The Internalization of Spiritual Based Characters Value In Building The Culture of Education organization. International Research-Based Education Journal, 1(1), 27-31. DOI: http://dx.doi.org/10.17977/um043v1i1p\%25p.

Koesoema, D. A. (2007). Pendidikan Karakter: Strategi Mendidik Anakdi Zaman Modern. Jakarta: PT Grasindo.

Lickona, T. (1992). Educating For Character: How Our School Can Teach Respect $\mathcal{E}$ Responsibility. New York: Bantam Books

Majid, A., \& Andayani, D. (2011). Pendidikan Karakter Perspektif Islam. Bandung: Remaja Rosdakarya.

Megawangi, R. (2007) Pendidikan Karakter Solusi Yang Tepat Untuk Membangun Bangsa. Bogor: Indonesia Heritage Foundation.

Moleong, L. J. (2006). Qualitative Research Methods: Revised Edition. Bandung: PT Remaja Rosdakarya.

Muadz, M. H. (2017). Sekolah Perjumpaan, Mataram, Gedung TGB Center; Dewan Pakar PBNW.

Muhaimin. (2012). Paradigma Pendidikan Islam. Bandung: Remaja Rosdakarya.

Mulyasa, E., (2011). Manajemen Pendidikan Karakter. Jakarta: Bumi Aksara.

Putrawan, A. D. (2018). Sekolah Perjumpaan Sebagai Gerakan Dakwah Berbasis Komunitas. Lentera: Jurnal Ilmu Dakwah dan Komunikasi, 2(2), 207-221. DOI: https://doi.org/10.21093/lentera.v2i2.1267.

Quddus, A. (2014). Menemukenali Tradisi Pendidikan Karakter Islam; Sebuah Ikhtiar Untuk NTB Yang Bermartabat. Seminar Dewan Research Daerah (DRD) Provinsi NTB. 
Suryabrata, S. (2006). Psikologi Pendidikan. Jakarta: PT. Raja Grafindo.

Taufik, M. (2017). Misi Profetik dalam Pembelajaran Humanistik-Transformatif: Studi Pada Pembelajaran Gelar Hidup di Lombok, NTB. Schemata, 6(1), 1-26. DOI: https://doi.org/10.20414/schemata.v6i1.833.

Uno, H. B. (2012) Orientasi Baru Dalam Psikologi Pembelajaran. Jakarta: Bumi Aksara.

Wahab. (2019). Sekolah Perjumpaan, in Policy Brief Penelitian "Pendidikan Karakter Pada Sekolah Perjumpaan di NTB”. Retrieved from: https://simlitbangdiklat.kemenag. go.id/. 